Bioeduca: Journal of Biology Education
$\frac{\text { http://iournal.walisongo.ac.id/index.php/bioeduca }}{\text { ISSN 2714-8009 (print), 2715-7490 (online) }}$
Volume 3, Nomor 2, Tahun 2021
Hal. 99 - 111

\title{
Analisis Hasil Penelitian Biologi Sebagai Sumber Belajar Materi Jaringan Pada Tumbuhan
}

\author{
Dyah Ayu Puspitasari ${ }^{1}$, Zuchrotus Salamah ${ }^{2}$ \\ ${ }^{1,2}$ Prodi Pendidikan Biologi, Universitas Ahmad Dahlan Yogyakarta \\ Email: dyah1600008134@webmail.uad.ac.id
}

\begin{tabular}{|c|c|}
\hline Informasi Artikel & ABSTRAK \\
\hline $\begin{array}{l}\text { Submit: } 24-01-2021 \\
\text { Diterima: } 15-09-2021 \\
\text { Dipublikasikan: } 30-09-2021\end{array}$ & $\begin{array}{l}\text { Peserta didik dalam pembelajaran biologi lebih banyak } \\
\text { menggunakan sumber belajar yang dikemas dalam bentuk buku } \\
\text { teks. Penggunaan buku teks materi jaringan tumbuhan perlu } \\
\text { didampingi oleh sumber belajar tambahan. Tujuan penelitian } \\
\text { untuk menentukan potensi hasil penelitian biologi sebagai } \\
\text { sumber belajar yang dikemas dalam bentuk handout. Jenis } \\
\text { penelitian adalah kualitatif deskriptif yaitu dengan } \\
\text { menginterpretasikan struktur anatomi yang diamati dan } \\
\text { selanjutnya hasil penelitian dianalisis secara deskriptif sesuai } \\
\text { syarat hasil penelitian dijadikan sumber belajar. Hasil penelitian } \\
\text { menunjukan hasil penelitian biologi berpotensi sebagai sumber } \\
\text { belajar materi jaringan pada tumbuhan yang dikemas dalam } \\
\text { bentuk bahan ajar berupa handout. } \\
\text { Kata kunci: jaringan pada tumbuhan potensi; hasil penelitian; } \\
\text { sumber belajar biologi }\end{array}$ \\
\hline Penerbit & ABSTRACT \\
\hline $\begin{array}{l}\text { Program Studi Pendidikan } \\
\text { Biologi, Fakultas Sains dan } \\
\text { Teknologi, UIN Walisongo } \\
\text { Semarang }\end{array}$ & $\begin{array}{l}\text { Students in learning biology mostly use learning resources that } \\
\text { are packaged in the form of textbooks. The use of plant tissue } \\
\text { material textbooks needs to be accompanied by additional } \\
\text { learning resources. The purpose of the study was to determine } \\
\text { the potential results of biological research as a learning resource } \\
\text { packaged in the form of handouts. The type of research is } \\
\text { descriptive qualitative, namely by interpreting the observed } \\
\text { anatomical structure and then the research results are analyzed } \\
\text { descriptively according to the requirements of the research } \\
\text { results as a learning resource. The results of the study show that } \\
\text { the results of biological research have the potential to be a } \\
\text { source of learning material for tissue in plants which are } \\
\text { packaged in the form of teaching materials in the form of } \\
\text { handouts. } \\
\text { Key words: tissue in plants; potential research results; biology } \\
\text { learning resources. }\end{array}$ \\
\hline
\end{tabular}

\section{PENDAHULUAN}

Keberhasilan proses pembelajaran didukung oleh faktor ketersediaan perangkat pembelajaran yang relevan. Perangkat pembelajaran yang biasa digunakan peserta didik dalam kegiatan pembelajaran biologi adalah sumber belajar. Sumber belajar merupakan segala sesuatu yang dapat memberikan kemudahan kepada peserta didik dalam memperoleh sejumlah informasi, pengetahuan dan 
ketrampilan dalam proses belajar mengajar. Menurut Nafsiyah (2020), sumber belajar dapat digunakan untuk mencapai tujuan pembelajaran. Hasil observasi yang dilakukan di sekolah dalam proses pembelajaran biologi yang dilakukan oleh peserta didik lebih banyak menggunakan sumber belajar yang dikemas dalam bentuk buku teks. Penggunaan sumber belajar buku teks dikarenakan peserta didik dapat meminjam di perpustakaan sekolah atau dapat membeli secara mandiri. Buku teks adalah bahan ajar yang disusun oleh seorang pengarang atau tim pengarang berdasarkan kurikulum yang berlaku (Prastowo, 2015:166-168).

Buku teks biologi Sekolah Menengah Atas kelas XI Semester 1 memuat Kompetensi Dasar (KD) Kurikulum 2013 "3.3. menganalisis keterkaitan antara struktur sel pada jaringan tumbuhan dengan fungsi organ pada tumbuhan". Beberapa buku teks biologi yang digunakan telah menyajikan materi tentang pengertian, ciri-ciri, fungsi epidermis dan materi tentang derivat epidermis namun, penyajian gambar dari buku teks masih terbatas hanya menyajikan gambar struktur epidermis dan derivat epidemis berupa stomata. Kurangnya penyajiaan gambar yang menunjang menjadikan buku teks kurang bervariasi untuk memberi penjelaskan kepada peserta didik.

Buku teks materi jaringan tumbuhan dalam penggunaannya sebaiknya perlu didampingi oleh sumber belajar tambahan. Hasil wawancara pada beberapa teman sejawat program studi Pendidikan Biologi Universitas Ahmad Dahlan pada tahun 2020 dapat disimpulkan bahwa sumber belajar yang dikemas dalam bentuk handout dapat dijadikan sebagai alternatif dalam mengatasi kelemahan dari buku teks biologi Sekolah Menengah Atas Kelas XI semester 1 pada materi jaringan pada tumbuhan. Penyusunan handout disesuaikan dengan kriteria penyusunan handout yang baik dan menampilkan catatan, gambar, tabel dan materi lainnya sehingga dapat digunakan untuk melengkapi kekurangan materi yang diberikan dalam buku teks (Prastowo, 2015:81-82). Handout dalam penyusunannya dapat diambil dari beberapa literatur yang relevan dengan materi pembelajaran. Salahsatunya, dari hasil penelitian biologi yang telah dilakukan oleh Puspitasari (2020), yaitu Identifikasi Karakteristik Epidermis dan Derivat pada Organ Daun Famili Gramineae di Lingkungan Pantai. Penelitian biologi memiliki produk hasil berupa fakta, prinsip dan konsep yang dapat di masukkan dalam materi pembelajaran biologi.

Beberapa penelitian tentang analisis potensi hasil penelitian biologi sebagai sumber belajar yang dilakukan oleh Dewi, Hindun, dan Wahyuni (2015:209-218) tentang "Studi Trikoma Daun pada Famili Solanaceae sebagai Sumber Belajar Biologi". Penelitian yang dilakukan oleh Dhaniaputri dan Irawati (2018:88-95) tentang "Pertumbuhan Organ Vegetatif Tomat Merah (Lycopersicum esculentum, L. var commune) dan Tomat Ungu (Lycopersicum esculentum, L. var indigo rose) sebagai Sumber Belajar Biologi SMA Kelas XII". Penelitian yang dilakukan menunjukkan bahwa hanya sampai pada tahap analisis potensi hasil penelitian memenuhi syarat sebagai sumber belajar biologi, sehingga perlu adanya penelitian tentang analisis potensi hasil penelitian memenuhi syarat sebagai sumber belajar dan pembuatan sumber belajar yang dikemas dalam bentuk bahan ajar. 
Penelitian ini bertujuan untuk menentukan potensi hasil penelitian sesuai dengan syarat sebagai sumber belajar dan selanjutnya dilakukan tahap-tahapan hasil penelitian dijadikan sebagai sumber belajar yang dikemas dalam bentuk bahan ajar berupa handout. Penelitian dilakukan sampai pada tahap pengemasan dalam bentuk bahan ajar yang belum sampai pada tahap validasi oleh ahli.

\section{METODE PENELITIAN}

Jenis penelitian yang digunakan yaitu jenis kualitatif deskriptif adalah penelitian yang menggambarkan, menginterpretasikan data (Al-busaidi, 2008). Data yang digunakan adalah data Karakteristik Epidermis dan Derivat pada Organ Daun Famili Gramineae di Lingkungan Pantai yang telah dilakukan oleh (Puspitasari, 2020). Selanjutnya, data dianalisis deskripsif tentang potensi hasil penelitian yang dapat dijadikan sumber belajar yang dikemas dalam bentuk bahan ajar. Menurut Suhardi (2012), tahapan hasil penelitian dapat dijadikan sebagai sumber belajar yaitu identifikasi hasil penelitian sesuai dengan persyaratan sumber belajar, identifikasi proses dan produk penelitian, seleksi dan modifikasi hasil penelitian sebagai sumber belajar, penerapan hasil penelitian sebagai sumber belajar biologi ke dalam organisasi instruksional, dan pengemasan sumber belajar menjadi bahan ajar. Penelitian dilakukan pada Bulan Juli sampai Agustus 2020 dilakukan di Universitas Ahmad Dahlan.

\section{HASIL PENELITIAN DAN PEMBAHASAN}

\section{Analisis Potensi Hasil Penelitian sebagai Sumber Belajar Biologi}

Hasil penelitian karakteristik epidermis dan derivat pada organ daun famili Gramineae di lingkungan pantai diperoleh data berupa gambar dan materi fakta tentang bentuk epidermis, tepi dinding sel epidermis, letak stomata, kondisi celah, bentuk sel penutup, tipe stomata, bentuk trikoma, tipe trikoma. Menurut Abdullah (2012), segala sesuatu seperti pesan, orang, bahan, alat, teknik, dan latar dapat dimanfaatkan oleh pendidik dan peserta didik untuk meningkatkan efektifitas, efisien dan menyenangkan dalam kelangsungan pembelajaran.

Hasil penelitian dapat diangkat menjadi sumber belajar biologi namun, perlu memenuhi persyaratan yaitu kejelasan potensi ketersediaan objek dan permasalahan yang diangkat, kesesuaian dengan tujuan pembelajaran, sasaran materi dan peruntukannya, informasi yang akan diungkap, pedoman eksplorasi dan perolehan yang akan dicapai (Suhardi, 2012).

Analisis hasil penelitian karakteristik epidermis dan derivat pada organ daun famili Gramineae di lingkungan pantai sebagai sumber belajar biologi yaitu sebagai berikut:

1. Kejelasan potensi ketersediaan objek dan permasalahan yang diangkat

Ketersediaan objek pada penelitian adalah karakteristik epidermis dan derivat (stomata dan trikoma) pada organ daun famili Gramineae di lingkungan pantai. Permasalahan yang diangkat pada penelitian adalah tumbuhan dari famili Gramineae banyak dijumpai dil ingkungan pantai yang memiliki karakteristik tanah berpasir. Tumbuhan ini dimanfaatkan oleh masyarakat sekitar untuk 
digunakan sebagai bahan pangan dan sebagai bahan pakan ternak. Penelitian tentang jaringan epidermis dan derivat berupa stomata dan trikoma pada organ daun famili Gramineae belum banyak dilakukan sehingga dapat digunakan sebagai objek penelitian dan hasilnya akan dipakai dalam sumber belajar biologi.

2. Kesesuaian dengan tujuan pembelajaran

Hasil penelitian sesuai dengan Kompetensi Dasar (KD) 3.3 pembelajaran biologi Sekolah Menegah Atas kelas XI berdasarkan kurikulum 2013, yaitu menganalisis keterkaitan antara struktur sel pada jaringan tumbuhan dengan fungsi organ pada tumbuhan. Kesesuaian dengan KD 4.3 pembelajaran biologi Sekolah Menegah Atas kelas XI berdasarkan kurikulum 2013, yaitu menyajikan data hasil pengamatan struktural jaringan dan organ pada tumbuhan. Kompetensi dasar dapat dirincikan menjadi tujuan pembelajaran.

Tujuan pembelajaran yaitu 1) peserta didik mampu menjelaskan pengertian derivat epidermis pada jaringan tumbuhan 2) Peserta didik mampu mengidentifikasi macam-macam derivat epidermis pada jaringan tumbuhan 3) Peserta didik mampu menggolongkan struktur epidermis pada tumbuhan sesuai dengan fungsi organ pada tumbuhan 3) Peserta didik mampu menganalisis keterkaitan struktur sel pada jaringan tumbuhan dengan fungsi organ pada tumbuhan 4) Peserta didik mampu menyajikan hasil pengamatan struktur jaringan pada jaringan dan organ tumbuhan.

3. Sasaran materi dan peruntukannya

Sasaran materi hasil penelitian adalah jaringan pada tumbuhan yaitu mengidentifikasi, menggolongkan, menganalisis, dan menyajikan hasil pengamatan struktur epidermis dan derivat berupa stomata dan trikoma pada organ daun famili Gramineae di lingkungan pantai. Sasaran peruntukannya adalah peserta didik Sekolah Menegah Atas kelas XI semester 1 mata pelajaran biologi pada Kompetensi Dasar (KD) Kurikulum 2013 "3.3. menganalisis keterkaitan antara struktur sel pada jaringan tumbuhan dengan fungsi organ pada tumbuhan". Menurut Ibda (2015), peserta didik pada usia 12 tahun keatas masuk pada tahap operasional formal sehingga memiliki kemampuan untuk berfikir abstrak dan mampu memahami bentuk pendapat lain.

4. Informasi yang diungkap

Informasi yang diungkap dapat dilihat pada dua aspek yaitu proses dan produk penelitian disesuaikan dengan kurikulum 2013. Informasi yang diungkap adalah karakteristik epidermis dan derivat pada organ daun famili Gramineae di lingkungan pantai. Karakteristik yang dimaksud adalah panjang dan lebar epidermis, bentuk epidermis, tepi dinding sel epidermis, panjang dan lebar stomata, indeks stomata, kerapatan stomata, letak stomata, kondisi celah, bentuk sel penutup, tipe stomata, bentuk trikoma, tipe trikoma, panjang trikoma, dan kerapatan trikoma.

5. Pedoman eksplorasi

Pedoman eksplorasi sesuai dengan prosedur kerja ilmiah yang dilakukan saat kegiatan penelitian eksplorasi yaitu penentuan sampel daun pada organ daun 
tumbuhan famili Gramineae yang digunakan dalam penelitian, alat dan bahan, cara kerja saat pengambilan sampel daun, pengukuran morfologi tumbuhan famili Gramineae, pengukuran parameter lingkungan, preparasi sampel, pengamatan preparat, dan pengolahan data, serta penarikan kesimpulan.

6. Perolehan yang akan dicapai

Perolehan yang akan dicapai hasil penelitian digunakan sebagai sumber belajar yaitu membantu peserta didik dalam mencapai tujuan pembelajaran yang dapat dilihat dari aspek kognitif (pengetahuan) dan aspek afektif (sikap). Ranah kognitif berkaitan dengan tujuan pembelajaran yang berorientasi pada kemampuan berpikir dan ranah afektif berhubungan dengan perasaan, emosi, sistem nilai dan sikap hati (Gunawan dan Paluti, 2012).

Ranah kognitif, dapat memberikan tambahan informasi dan pengetahuan kepada peserta tentang karakteristik struktur anatomi epidermis seperti panjang dan lebar sel, bentuk sel, dan tepi dinding sel. Karakteristik struktur anatomi derivat epidermis berupa stomata dan trikoma seperti panjang dan lebar stomata, letak stomata, indeks stomata, kerapatan stomata, kondisi celah, bentuk sel penutup, tipe stomata, bentuk trikoma, tipe trikoma, panjang trikoma, dan kerapatan trikoma. Anatomi dilihat pada organ daun famili Gramineae terutama pada spesies Dactyloctenium aegyptium, Chloris barbata, dan Polytrias indica yang berada di lingkungan pantai karena dalam pertumbuhan dan perkembangannya dapat dipengaruhi oleh lingkungan tumbuh.

Identifikasi yang telah dilakukan menunjukkan karakteristik struktur anatomi epidermis pada organ daun famili Gramineae di lingkungan pantai memiliki panjang sel epidermis bentuk epidermis segi 4 memanjang, dan tepi dinding sel berlekuk-lekuk. Karakteristik struktur derivat epidermis berupa stomata dan trikoma organ daun memiliki ukuran yang berbeda-beda pada setiap permukaan adaksial dan abaksial setiap spesies, panjang, lebar, indeks dan kerapatan setiap permukaan adaksial dan abaksial setiap spesies. Selain itu, stomata ditemukan pada permukaan adaksial dan permukaan abaksial, kondisi celah tertutup, bentuk sel penutup halter, tipe stomata parasitik. Trikoma pada tepi dan tengah permukaan daun memiliki bentuk rambut, memiliki tipe trikoma uniseluler, memiliki panjang dan kerapatan berbeda-beda pada permukaan adaksial dan abaksial setiap spesies.

Ranah afektif menunjukkan penerimaan dan tanggapan peserta didik terhadap pembelajaran (Khanifah, Pukan, dan Sukaesih, 2012). Penilaian ranah afektif diperoleh dengan mengamati sikap peserta didik dalam pembelajaran menggunakan lembar observasi. Aspek yang diamati adalah sikap disiplin, tanggung jawab, dan kerjasama peserta didik yang dilakukan dalam kegiatan individu maupun kerja kelompok. Diskusi dilakukan saat menyelesaikan soal yang berkaitan dengan hasil penelitian memerlukan kerjasama, sehingga setiap peserta didik dibutuhkan sikap disiplin dan tanggung jawab untuk menyelesaikannya. 
Hasil analisis hasil penelitian tentang Karakteristik Epidermis dan Derivat pada Organ Daun Famili Gramineae di Lingkungan Pantai berpotensi sebagai sumber belajar biologi. Selaras dengan penelitian yang dilakukan oleh Dewi, Hindun, dan Wahyuni (2015:209-218) serta Wijaya, Zubaidah, dan Kuswantor (2016), hasil penelitian biologi dapat dijadikan sebagai sumber belajar biologi Sekolah Menengah Atas karena memenuhi syarat hasil penelitian dapat dijadikan sebagai sumber belajar. Berbeda dengan penelitian yang telah dilakukan pada penelitian ini dilanjutkan pada tahapan hasil penelitian biologi dijadikan sebagai sumber belajar.

\section{Tahapan Hasil Penelitian Biologi Dijadikan sebagai Sumber Belajar}

Tahap selanjutnya setelah hasil penelitian memenuhi syarat sebagai sumber belajar maka dapat dilanjutkan ketahap-tahapan hasil penelitian dijadikan sebagai sumber belajar. Menurut Suhardi (2012), tahap hasil penelitian dijadikan sebagai sumber belajar melalui tahapan yaitu identifikasi proses dan produk penelitian, seleksi dan modifikasi penelitian sebagai sumber belajar biologi, penerapan hasil penelitian sebagai sumber belajar biologi ke dalam organisasi instruksional, serta pengemasan sumber belajar menjadi bahan ajar. Tahap-tahapan yang dilakukan yaitu sebagai berikut:

1. Identifikasi proses dan produk penelitian

Identifikasi proses disesuaikan dengan langkah-langkah penelitian tahap pertama eksplorasi yaitu identifikasi masalah, perumusan masalah, perumusan tujuan penelitian, penyusunan prosedur penelitian, pelaksanaan penelitian, pengumpulan dan analisis data hasil penelitian, pembahasan, dan penarikan kesimpulan. Hasil analisis segi proses hasil penelitian eksplorasi sebagai sumber belajar biologi dapat dilihat pada tabel 1. sebagai berikut:

Tabel 1. Hasil Analisis Segi Proses Hasil Penelitian sebagai Sumber Belajar

\begin{tabular}{|c|c|c|}
\hline No & $\begin{array}{c}\text { Langkah } \\
\text { Kerja Ilmiah } \\
\text { Segi Proses }\end{array}$ & Penjelasan \\
\hline 1 & $\begin{array}{l}\text { Identifikasi } \\
\text { Perumusan } \\
\text { Masalah }\end{array}$ & $\begin{array}{l}\text { Identifikasi masalah dalam penelitian yaitu sebagai berikut: } \\
\text { a. Penelitian tentang jaringan epidermis dan derivat berupa stomata } \\
\text { dan trikoma belum bnyak dilakukan pada organ daun famili } \\
\text { Gramineae. } \\
\text { b. Kawasan Pantai Parangtritis sampai Depok kurang memenuhi } \\
\text { sebagi tempat tumbuh tumbuhan. } \\
\text { c. Bentuk adaptasi tumbuhan di lingkungan tumbuh dapat } \\
\text { menyebabkan struktur anatomi yang beragam pada organ daun. } \\
\text { Perumusan masalah dalam penelitan sebagai berikut: } \\
\text { a. Bagaimana karakteristik jaringan epidermis pada organ daun famili } \\
\text { Gramineae di Lingkungan Pantai? } \\
\text { b. Bagaimana karakteristik derivat epidermis pada organ daun famili } \\
\text { Gramineae di Lingkungan Pantai? }\end{array}$ \\
\hline 2 & $\begin{array}{l}\text { Perumusan } \\
\text { Tujuan } \\
\text { Penelitian }\end{array}$ & $\begin{array}{l}\text { Tujuan dalam penelitian yaitu sebagai berikut: } \\
\text { a. Menentukan karakteristik jaringan epidermis pada organ daun } \\
\text { famili Gramineae di Lingkungan Pantai } \\
\text { b. Menentukan karakteristik derivat epidermis pada organ daun famili } \\
\text { Gramineae di Lingkungan Pantai }\end{array}$ \\
\hline
\end{tabular}


Prosedur penelitian atau cara kerja yang dilakukan dalam penelitian Prosedur yaitu sebagai berikut:

Penelitian a. Sampel daun pada famili Gramineae diambil di Lingkungan Pantai

b. Lingkungan tempat pengambilan sampel dilakukan pengukuran suhu, kelembaban udara, kelembaban, ph tanah, intensitas cahaya, kecepatan angin dan titik koordinat.

c. Sampel daun dilakukan preparasi di Laboratorium Terpadu Biologi Universtitas Ahmad Dahlan.

d. Preparat daun dilakukan pengamatan pada struktur anatomi jaringan epidermis dan derivatnya di Laboratorium Terpadu Biologi Universitas Ahmad Dahlan.

\begin{tabular}{|c|c|c|}
\hline & $\begin{array}{l}\text { Langkah } \\
\text { Kerja Ilmiah } \\
\text { Segi Proses }\end{array}$ & Penjelasan \\
\hline 4 & $\begin{array}{l}\text { Pelaksanaan } \\
\text { Kegiatan }\end{array}$ & $\begin{array}{l}\text { Pelaksanaan kegiatan penelitian dilakukan pada bulan Juli sampai } \\
\text { Agustus 2020. Penelitian dilaksanakan di Sepanjang Pantai } \\
\text { Parangtritis sampai Depok dan Laboratorium Terpadu Biologi } \\
\text { Universitas Ahmad Dahlan. }\end{array}$ \\
\hline 5 & $\begin{array}{l}\text { Pengumpulan } \\
\text { dan Analisis } \\
\text { Data }\end{array}$ & $\begin{array}{l}\text { Pengumpulan data dalam penelitian yaitu sebagai berikut: } \\
\text { a. Pengumpulan data eksplorasi dilakukan dengan observasi dan } \\
\text { dokumentasi berupa bentuk epidermis, dinding sel epidermis, } \\
\text { panjang dan lebar epidermis, letak stomata, panjang dan lebar } \\
\text { stomata, indeks stomata, kerapatan stomata, kondisi celah } \\
\text { stomata, bentuk sel penutup, tipe stomata, bentuk trikoma, tipe } \\
\text { trikoma, panjang trikoma dan kerapatan trikoma. } \\
\text { Analisis data dalam penelitian yaitu sebagai berikut: } \\
\text { a. Analisis data eksplorasi dilakukan secara kulitatif deskriptif. }\end{array}$ \\
\hline 6 & $\begin{array}{l}\text { Pembahasan } \\
\text { Hasil } \\
\text { Penelitian }\end{array}$ & $\begin{array}{l}\text { Hasil penelitian tentang Identifikasi Karaktersitik Epidermis dan Derivat } \\
\text { pada Organ Daun Famili Gramineae di Lingkungan Pantai dibahas } \\
\text { sesuai dengan sumber yang relevan. }\end{array}$ \\
\hline 7 & $\begin{array}{l}\text { Penarikan } \\
\text { Kesimpulan }\end{array}$ & $\begin{array}{l}\text { Penarikan kesimpulan pada penelitian eksploratif adalah sebagai } \\
\text { berikut: } \\
\text { a) Karakteristik jaringan epidermis organ daun pada famili Gramineae } \\
\text { di Lingkungan Pantai memiliki bentuk segi } 4 \text { memanjang dengan } \\
\text { tepi dinding sel berlekuk-lekuk. } \\
\text { b) Karakteristik derivat epidermis organ daun pada famili Gramineae } \\
\text { di Lingkungan Pantai yaitu tipe parasitik, kondisi celah tertutup, } \\
\text { panjang, lebar, indeks dan kerapatan yang berbeda pada kedua } \\
\text { permukaan daun, trikoma pada permukaan tengah daun dan tepi } \\
\text { daun memiliki bentuk rambut, panjang, lebar dan kerapatan yang } \\
\text { berbeda-beda. }\end{array}$ \\
\hline
\end{tabular}

Selanjutnya, dilakukan identifikasi dari segi produk. Hasil penelitian tahap pertama eksplorasi mendapatkan fakta tentang karakteristik epidermis dan derivat organ daun pada famili Gramineae di lingkungan pantai yang dapat digeneralisasikan menjadi konsep dan prinsip. Hasil analisis segi produk terhadap hasil penelitian dapat dijadikan sebagai sumber belajar dapat dilihat pada tabel 2 . sebagai berikut:

Tabel 2. Identifikasi Segi Produk Hasil Penelitian sebagai Sumber Belajar

No Segi Produk Penjelasan




$\begin{array}{lll}1 \text { Fakta } & \text { Materi Fakta yang ditemukan pada hasil penelitian: } \\ & \text { a) Jaringan epidermis pada organ daun ditemukan pada permukaan } \\ & \text { adaksial dan permukaan abaksial. } \\ & \text { b) Jaringan epidermis di kedua permukaan daun ditemukan derivat } \\ & \text { epidermis berupa stomata dan trikoma. } \\ & \text { Materi konsep yang ditemukan pada hasil penelitian: } \\ & \text { a) Jaringan epidermis pada organ daun pada permukaan adaksial dan } \\ & \text { permukaan abaksial memiliki ukuran yang berbeda. } \\ & \text { b) Derivat epidemis berupa stomata dan trikoma dapat memiliki bentuk, } \\ & \text { panjang, lebar, kerapatan, dan indeks yang berbeda-beda. } \\ & \text { Materi prinsip yang ditemukan pada hasil penelitian: } \\ & \text { a) Jaringan epidermis pada organ daun pada permukaan adaksial dan } \\ & \text { permukaan abaksial memiliki ukuran yang berbeda-beda karena } \\ & \text { dapat dipengaruhi faktor lingkungan. } \\ \text { b) } \begin{array}{l}\text { Derivat epidemis berupa stomata dan trikoma dapat memiliki } \\ \text { bentuk,panjang,lebar, kerapatan, dan indeks yang berbeda-beda } \\ \text { karena dapat dipengaruhi faktor lingkungan. }\end{array}\end{array}$

Hasil penelitian yang akan digunakan sebagai tambahan informasi dan ilmu pengetahuan kepada peserta didik kelas XI dapat berupa fakta, konsep dan prinsip. Menurut Prastowo (2015:44-45), fakta adalah segala hal yang berwujud kenyataan dan kebenaran, konsep adalah segala hal yang berwujud pengertian baru yang timbul dari hasil pemikiran serta prinsip adalah hal-hal pokok yang menggambarkan implikasi sebab-akibat. Hasil penelitian berupa fakta, konsep dan prinsip dapat melatih peserta didik untuk berpikir secara deduktif, induktif, hipotetis dan logis. Hal ini dapat membuat peserta didik untuk mengingat materi pembelajaran yang telah dipelajari sebelumnya. Menurut Rahmah (2013), pembelajaran dapat bermakna karena peserta didik dapat mengaitkan informasi baru dengan konsep-konsep relevan yang terdapat fakta, konsep, dan generasi lain yang telah dipelajari dan dari ingatan peserta didik.

2. Seleksi dan modifikasi penelitian sebagai sumber belajar biologi

Tahap selanjutnya adalah seleksi dan modifikasi hasil penelitian sebagai sumber belajar. Seleksi dan modifikasi dilakukan untuk menyeleksi materi yang dapat digunakan untuk sumber belajar agar sesuai dengan kompetensi dasar 3.3 dan 4.3 kelas XI mata pelajaran biologi. Hasil seleksi dan modifikasi hasil penelitian dalam prosedur kerja penelitian atau proses dapat dilihat pada tabel 3 sebagai berikut:

Tabel 3. Seleksi dan Modifikasi Proses Hasil Penelitian sebagai Sumber Belajar Prosedur Penelitian Seleksi dan Modifikasi

Prosedur penelitian yang dilakukan dalam Hasil seleksi proses hasil penelitian eksplorasi penelitian eksplorasi yaitu sebagai berikut:
a) Sampel daun pada famili Gramineae diambil di lingkungan pantai.
b) Lingkungan tempat pengambilan sampel dilakukan pengukuran parameter lingkungan.
c) Sampel daun dilakukan preparasi di Laboratorium Terpadu Biologi Universtitas Ahmad Dahlan.
d) Preparat daun dilakukan pengamatan sebagai sumber belajar:
a) Preparat organ daun pada famili Gramineae dilakukan pengamatan pada struktur anatomi epidermis dan derivatnya.

Hasil modifikasi proses hasil penelitian sebagai sumber belajar:

a) Peserta didik tidak melakukan pengamatan struktur anatomi epidermis dan derivat pada organ daun famili Gramineae secara langsung menggunakan mikroskop, namun 
Menurut Suhardi (2012:7-11), hasil penelitian dijadikan sebagai sumber belajar merupakan salah satu sumber belajar by design. Sumber belajar by design merupakan sumber belajar yang secara khusus dikembangkan untuk memberikan fasilitas belajar (Siregar dan Nara, 2015:127-135). Tabel 3. Menunjukkan hasil seleksi hasil penelitian yaitu kegiatan pembelajaran dilakukan peserta didik di dalam kelas sehingga peserta didik tidak melakukan pengamatan struktur anatomi epidermis dan derivat organ daun famili Gramineae secara langsung menggunakan mikroskop, namun peserta didik akan mengamati struktur anatomi epidermis dan derivat organ daun famili Gramineae melalui gambar. Menurut Prastowo (2015:99-100), gambar yang digunakan dalam handout dapat bermanfaat untuk dekorasi sehingga membuat bahan ajar menjadi menarik, membantu untuk membayangkan pesan yang ingin disampaikan, memperjelas informasi yang akan disampaikan agar mudah dipahami, satu gambar dapat menjelaskan beberapa kata dan penyederhanaan cara penyampaian tanpa mengurangi konsep.

Seleksi dan modifikasi produk hasil penelitian sebagai sumber belajar dapat dilihat pada tabel 4. sebagai berikut:

Tabel 4. Seleksi dan Modifikasi Segi Produk Hasil Penelitian sebagai Sumber Belajar

\begin{tabular}{cll}
\hline No & Segi Produk & \multicolumn{1}{c}{ Penjelasan } \\
\hline 1 & Fakta & Materi Fakta yang ditemukan pada hasil penelitian: \\
& C) Jaringan epidermis pada organ daun ditemukan pada & permukaan adaksial dan permukaan abaksial. \\
& d) $\begin{array}{l}\text { Jaringan epidermis di kedua permukaan daun ditemukan } \\
\text { derivat epidermis berupa stomata dan trikoma. }\end{array}$ \\
& Materi konsep yang ditemukan pada hasil penelitian: \\
& C) Jaringan epidermis pada organ daun pada permukaan \\
& adaksial dan permukaan abaksial memiliki bentuk dan tepi \\
& dinding sel yang sama.
\end{tabular}

Hasil penelitian berupa fakta, konsep dan prinsip dilakukan seleksi dan modifiasi sesuai dengan kompetensi dasar 3.3 dan 4.3 kelas XI mata pelajaran 
biologi. Sehingga, hasil penelitian berupa fakta dan, konsep dan prinsip dapat dimasukkan kedalam materi sumber belajar.

3. Penerapan hasil penelitian sebagai sumber belajar biologi ke dalam organisasi instruksional

Hasil penelitian diwujudkan dalam organisasi instruksional seperti Rencana Pelaksanaan Pembelajaran (RPP) agar dalam proses pembelajaran dapat berjalan sesuai dengan tujuan pembelajaran. Menurut Jailani (2016:175-192), guru memiliki peran dalam mendesain pembelajaran seperti merumuskan tujuan yang akan diajarkan, memiliki banyak sumber belajar, mampu memanfaatkan sumber belajar, merencanakan kegiatan, menguasai pengertian tujuan dan teknik evaluasi, mengembangkan komponen yang berfungsi untuk intekasi dalam belajar, dan perencenaan untuk antisipasi tentang apa yang akan dilakukan saat proses belajar.

Sumber belajar yang didapatkan dari hasil penelitian dan yang telah disesuaikan dengan tujuan pembelajaran disebut dengan sumber belajar by designed. Menurut Siregar dan Nara (2015:129) sumber belajar by design ialah sumber belajar yang memang diperuntukan untuk kepentingan belajar. Menurut Heriadon dan Manurung (2016:188-195), guru secara langsung bertanggung jawab atas keberhasilan proses pembelajaran yang dikembangkan khususnya didalam kelas, karena faktor yang mempengaruhi keberhasilan peserta didik tidak hanya pada diri peserta didik melainkan dapat berasal dari luar diri siswa salah satunya dari pengalaman belajar.

4. Pengemasan sumber belajar menjadi bahan ajar

Hasil penelitian berbentuk materi dan gambar. Salahsatu, bahan ajar yang dapat memuat materi dan gambar adalah handout. Handout adalah bahan ajar yang disiapkan oleh seorang pendidik untuk memperkaya pengetahuan peserta didik yang diambilkan dari beberapa literatur. Selaras dengan penelitian yang dilakukan oleh Ningtyas, Yunianta, dan Wahyudi (2014:42-53), handout yang dikembangkan berupa gambar seri yang dapat meningkatkan pemahan peserta didik dan memberikan tampilan dan gambar yang menarik karena bahan ajar yang pernah digunakan hanya berupa latihan soal dengan kertas Buram.

Penyusunan handout harus disesuaian dengan komponen bahan ajar. Komponen yang terdapat pada handout yaitu cover, berupa halaman depan yang memuat judul handout, gambar yang mewakili isi handout, gambar dan nama penulis. Identitas dan petunjuk belajar, berisi panduan dal am menggunakan handout. Kompetensi inti, kompetensi dasar, indikator dan tujuan pembelajaran. Materi pelajaran, berisi cakupan materi yang akan dipaparkan. Paparan materi, berisi penjelasan materi dari indikator yang akan dicapai. Latihan, berisi pertanyaan-pertanyaan yang berupa soal-soal dalam bentuk essay yang bisa dikerjakan peserta didik. Daftar pustaka, berisi referensi-referensi yang digunakan (Saf dan Yurnetti, 2019:713-720).

Handout memiliki struktur yaitu informasi tambahan yang memuat materi untuk memperlancar dan memperkaya pengetahuan peserta didik. Pengemasan 
dalam bentuk handout karena dapat digunakan sebagai sumber belajar tambahan untuk melengkapai buku teks pembelajaran biologi materi jaringan pada tumbuhan sub materi jaringan epidermis dan derivatnya yang digunakan oleh peserta didik. Menurut Prastowo (2015:81), handout dalam penggunaanya dapat digunakan sebagai tambahan kekurangan materi yang terdapat pada buku teks maupun materi yang disampaikan oleh guru karena dapat berisi materi, tebel, diagram, tabel bahkan gambar. Selaras dengan Agustina, Nugroho, dan Mulyani (2013:66-71), handout dapat digunakan dapat digunakan sebagai sumber dalam kegiatan diskusi kelompok dan handout dapat pula digunakan secara mandiri oleh peserta didik.

Tahap-tahapan yang telah dilakukan menunjukkan bahwa hasil penelitian Karakteristik Epidermis dan Derivat pada Organ Daun Famili Gramineae di Lingkungan Pantai dapat sebagai sumber belajar yang dikemas dalam bahan ajar berupa handout. Menurut penelitian yang telah dilakukan oleh Yana, Syakbaniah, dan Kamus (2014:9-16) dan Hera, Khairil, \& Hasanuddin (2014:223_229) dapat meningkatkan pemahan konsep yang dapat dilihat pada nilai pretest dan postest yang dilakukan peserta didik. Diharapkan dalam pembuatan sumber belajar yang dikemas dalam bentuk handout yang berasal dari hasil penelitian dapat menambah pemahaman dan sebagai informasi tambahan bagi peserta didik pada materi jaringan pada tumbuhan khususnya sub materi jaringan epidermis dan derivatnya.

\section{SIMPULAN DAN SARAN}

Hasil penelitian biologi berpotensi sebagai sumber belajar materi jaringan pada tumbuhan yang dikemas dalam bentuk bahan ajar handout. Hasil dari penelitian perlu dilakukan analisis lebih lanjut dan dikembangkan melalui penelitian dan pengembangan (R\&D) bahan ajar.

\section{UCAPAN TERIMA KASIH}

Ucapan terimakasih disampaikan kepada Dra. Zuchrotus Salamah, M.Si. selaku pembimbing dalam penelitian Karakteristik Epidermis dan Derivat pada Organ Daun Famili Gramineae di lingkungan pantai pada tahun 2020.

\section{RUJUKAN}

Abdullah, R. (2012). Pembelajaran Berbasis Pemanfaatan Sumber Belajar. Jurnal IImiah Didaktika, 12(2), 216--231.

Agustina, E., Nugroho, A., \& Mulyani, S. (2013). Penggunaan Metode Pembelajaran Jigsaw Berbantuan Handout untuk Meningkatan Aktivitas dan Prestasi Belajar Siswa pada Materi Pokok Hidrokarbon Kelas XC SMA Negeri 1 Gubug Tahun Ajaran 2012/2013. Jurnal Pendidikan Kimia (JKP), 2(4), 66-71.

Al-busaidi, Z. Q. (2008). Qualitative Research and its Uses in Health Care. Sultan Qaboos University Medical Journal, 8(1), 11-19.

Dewi, V. P., Hindun, I., \& Wahyuni, S. (2015). Studi Trikoma Daun pada Famili Solanaceae sebagai Sumber Belajar Biologi. Jurnal Pendidikan Biologi Indonesia, 1(2), 209-218. https://doi.org/10.22219/jpbi.v1i2.3332

Dhaniaputri, R., \& Irawati, H. (2018). Pertumbuhan Organ Vegetatif Tomat Merah 
(Lycopersicum esculentum, L. var commune) dan Tomat Ungu (Lycopersicum esculentum, L. var indigo rose) Sebagai Sumber Belajar Biologi SMA Kelas XII. Bioeduscience, 2(1), 88. https://doi.org/10.29405/j.bes/87-94121383

Gunawan, I., \& Paluti, A. R. (2012). Premiere Educandum. E-Journal.Unipma, 2(02), 98-117. https://doi.org/http://doi.org/10.25273/pe.v2i02.50

Hera, R., Khairil, \& Hasanuddin. (2014). Pengembangan Handout Pembelajaran Embriologi Berbasis Kontekstual Pada Perkuliahan Perkembangan Hewan Untuk Meningkatkan Pemahaman Konsep Mahasiswa Di Universitas Muhammadiyah Banda Aceh. Jurnal EduBio Tropika, 2(2), 223-229.

Heriadon, T., \& Manurung, T. (2016). Analisis Rencana Pelaksanaan Pembelajaran Biologi Kelas XI IPA Berbasis KTSP dan Korelasinya terhadap Hasil Belajar Siswa di SMA Negeri 1 Parbuluan T.P 2014/2015. Jurnal Pelita Pendidikan, 4(1), 188-195.

Ibda, F. (2015). Perkembangan Kognitif: Teori Jean Piaget. Intelektualita, 3(1), 242904.

Irnaningtyas, \& Istiadi, Y. (2014). Buku Siswa Biologi untuk SMA/MA Kelas XI Peminatan Matematika dan IImu-ilmu Alam. Jakarta: Erlangga.

Jailani, M. sahran. (2016). Pengembangan Sumber Belajar Berbasis Karakter Peserta Didik (Ikhtiar optimalisasi Proses Pembelajaran Pendidikan Agama Islam (PAI)). Nadwa (Jurnal Pendidikan Islam), 10(2), 175-192. https://doi.org/10.21580/nw.2016.10.2.1284

Khanifah, S., Pukan, K. K., \& Sukaesih, S. (2012). Pemanfaatan Lingkungan Sekolah Sebagai Sumber Belajar Untuk Meningkatkan Hasil Belajar Siswa. Journal of Biology Education, 1(1), 66-73.

Nafsiyah, F. (2020). Pengembangan Booklet Keanekaragaman Lepidoptera Subordo Rhopalocera di Kawasan Cagar Alam Pagerwunung Darupono Kendal sebagi Sumber Belajar Biologi pada Materi Keanekaragaman Hayati di MA NU 03 Sunan Katong Kaliwungu Kendal. Biodeuca, 02(1), 1-11.

Ningtyas, R., Yunianta, T. N. H., \& Wahyudi, W. (2014). Pengembangan Handout Pembelajaran Tematik Untuk Siswa Sekolah Dasar Kelas III. Scholaria: Jurnal Pendidikan Dan Kebudayaan, 4(3), 42-53. https://doi.org/10.24246/j.scholaria.2014.v4.i3.p42-53

Prastowo, A. (2015). Panduan Kreatif Membuat Bahan Ajar Inovatif. Yogyakarta: DIVA Press.

Puspitasari, D. A. (2020). Identifikasi Karakteristik Organ Daun Famili Gramineae di Sepanjang Pantai Parangtritis Sampai Depok Sebagai Sumber Belajar Biologi. Skripsi. Universitas Ahmad Dahlan. Yogyakarta.

Rahmah, N. (2013). Belajar Bermakna Ausubel. Al-Khwarizmi: Jurnal Pendidikan Matematika Dan Ilmu Pengetahuan Alam, 1(1), 43-48. https://doi.org/10.24256/jpmipa.v1i1.54

Saf, K. I., \& Yurnetti. (2019). Validasi Handout Fisika Pembelajaran Kontekstual pada Materi Gelombang Berjalan Stasioner Bunyi dan Cahaya Kelas XI SMA/MA. Pillar of Physics Education, 12(4), 713-720.

Siregar, E., \& Nara, H. (2015). Teori Belajar dan Pembelajaran. Bogor: Ghalia Indonesia.

Suhardi. (2012). Pengembangan Sumber Belajar Biologi. Yogyakarta: UNY Press. Wijaya, I., Zubaidah, S., \& Kuswantor, H. (2016). Anatomi Daun Galur-Galur Harapan Kedelai (Glycine Max L. Merill) Tahan CPMMV (Cowpea Mild Mottle Virus) sebagai Sumber Belajar. Jurnal Pendidikan, 1(3), 463-467. Retrieved from http://fkip.ummetro.ac.id/journal/index.php/biologi/article/view/484 
Yana, A. S., Syakbaniah, \& Kamus, Z. (2014). Pengembangan Handout Bebrbasis Model Sains Teknologi Masyarakat Pada Materi Wujud Zat Dan Perubahan Zat Untuk Pembelajaran Ipa Fisika Smp Kelas Vii Semester 1. Pillar of Physics Education, 3(April), 9-16. 